\title{
Assessing the Suitability and Availability of Land for Agriculture in Tuban Regency, East Java, Indonesia
}

\author{
Widiatmaka, ${ }^{1}$ Wiwin Ambarwulan, ${ }^{2}$ Yudi Setiawan, ${ }^{3}$ and Christian Walter ${ }^{4}$ \\ ${ }^{1}$ Department of Soil Science and Land Resources, Bogor Agricultural University, Jalan Meranti, Kampus IPB Darmaga, \\ Bogor 16680, Indonesia \\ ${ }^{2}$ Geospatial Information Agency, Jalan Raya Jakarta-Bogor Km. 46, Cibinong, Bogor 16911, Indonesia \\ ${ }^{3}$ Center for Environmental Research, Gedung PPLH, Kampus IPB Darmaga, Bogor 16680, Indonesia \\ ${ }^{4} U M R$ SAS, Agrocampus Ouest, INRA, 65 Rue de Saint-Brieuc, 35000 Rennes, France
}

Correspondence should be addressed to Widiatmaka; widi.widiatmaka@yahoo.com

Received 16 March 2016; Revised 6 June 2016; Accepted 9 June 2016

Academic Editor: Marco Trevisan

Copyright (C) 2016 Widiatmaka et al. This is an open access article distributed under the Creative Commons Attribution License, which permits unrestricted use, distribution, and reproduction in any medium, provided the original work is properly cited.

Indonesian food production depends highly on Java Island, which holds the most fertile soils in the country but had limited area. The objective of the research was to analyse the availability of suitable land for agriculture in Tuban Regency, an agricultural regency in Java Island. Land suitability was evaluated with spatial multicriteria analysis, integrating soil order, land capability, elevation, slope, slope direction, land use/land cover, accessibility, and climate. Land availability was analysed, integrating the forest area status designation and the spatial pattern of regional official land use plan. The results indicated that suitable land for agriculture corresponds to $91 \%$ of the total study area, confirming the high soil fertility. Analysis of land availability then indicated that $18 \%$ of the area was both suitable and available for agriculture. Considering the actual land utilization, the future development of agriculture in the region has less than $7 \%$ of the land area left for agricultural expansion. The overall results showed the importance of looking for land allocated for agriculture outside Java Island to anticipate the need for food of a country with a high population growth rate and also developing planning for food production.

\section{Introduction}

The world is increasingly felt smaller because of rapid population growth that has resulted in an increasing need for land. The fact that land has to be used by many sectors and that there is the necessity to meet growing food demand in a sustainable way means that land use planning is necessary [1]. The core of land use planning is the land suitability for a given utilization; therefore, it is necessary to evaluate land suitability [2]. Land evaluation is the assessment process of land performance for specific purposes $[2,3]$. Assessment results can then be used to predict the land's potency for certain utilizations [3]. The selection of land is important, because using unsuitable land will have implication for low production, which in turn results in the inefficient utilization of resources [4].

Land evaluation is done through assessment of land quality and land characteristics indicators in terms of physical aspects as well as economic, social, and environmental aspects $[2,5]$. Facilitated by recent advances in technology, land evaluation was developed in integrated ways, based on multicriteria decision-making concept $[6,7]$. The combination of analytical hierarchy process (AHP) with geographic information system (GIS) in a method which is known as multicriteria analysis (MCA) is one of the methods of decision-making in land use planning [8]. MCA has been used for various purposes, including agriculture [9].

Practically, land suitability alone would not be sufficient for planning land utilization. Land which is suitable for a given use may actually have been used for or have been allocated for another use. Therefore, when planning land utilization, it becomes important to conduct land availability analysis as well. The problem for the agricultural sector is that often the land utilization for agriculture is surpassed by the use of a variety of other sectors because agriculture has 
a lower land rent, for example, compared with industrial and residential land utilization [10].

Such a situation has occurred on Java Island, Indonesia, which is the most fertile island in the country. The island has been the main food provider of the country; however, due to increasingly rapid population growth, nonagricultural land utilization has increasingly put pressure on agricultural land, in turn putting pressure on national food security [14]. The data from the last census indicated that the population of Indonesia was 237 million in 2010 [15] and has been estimated to become 255 million in 2015 [16], an increase of $7.6 \%$ during last 5 years. This number makes Indonesia become the fourth largest country in the world by population. Rice is the staple food for $95 \%$ of the Indonesian population [17]; however, most rice was produced from paddy fields in Java Island. Of the total 13.8 million ha of paddy fields in Indonesia, 6.5 million ha or $46.7 \%$ was in Java Island [18]. The paddy fields in Java Island produced $52.6 \%$ of Indonesia's total rice production, suggesting the very high Indonesia's dependence on Javanese agriculture. The problem is that Java Island is an island with a limited area that is inhabited by the majority of the Indonesian population. More than 136 million people or $57.5 \%$ of the population [17] lived on this island. With the island's area making up less than $7 \%$ of the total area of Indonesia [17], the very high dependence on Javanese agriculture is very risky for future national food security. In this most populous island, there is high pressure on agricultural land due to the need for infrastructure such as housing, roads, and industry.

Tuban Regency is one of the agrarian regencies in Java Island, with a population density of 701 person $\mathrm{km}^{-2}$ [19], which signifies that the regency is less populated for a Javanese regency. In comparison, the average population density of Java Island was 3,408 person $\mathrm{km}^{-2}$ in 2014 [17], while the density of Jakarta, Indonesian capital, was 15,015 person $\mathrm{km}^{-2}$ [17]. The methodology for this study was developed to investigate whether lands with high suitability level are available for agriculture and if this agrarian regency still can be developed for agriculture.

The objectives of this study were (i) to delineate the land at various levels of suitability for agriculture and (ii) to examine how many of such suitable lands are available for agriculture. The output of the study may provide the information for developing policy that needs to be set in relation to Indonesia's high dependence on Javanese agricultural production.

\section{Materials and Methods}

2.1. Research Area. The study was conducted in Tuban Regency, East Java Province, which is geographically located at $111^{\circ} 34^{\prime} 11^{\prime \prime}$ to $112^{\circ} 13^{\prime} 23^{\prime \prime}$ east and $6^{\circ} 45^{\prime} 10^{\prime \prime}$ to $7^{\circ} 9^{\prime} 57^{\prime \prime}$ south (Figure 1). The study area has a wet tropical climate with an average annual rainfall of $2,132.7 \mathrm{~mm}$ [19]. The monthly average temperature ranges from $26.6^{\circ} \mathrm{C}$ to $28.9^{\circ} \mathrm{C}$. The elevation of the study area ranges between $0 \mathrm{~m}$ and $500 \mathrm{~m}$ above sea level (a.s.l.). The north and south parts of the study area are lowlands with a height of $0-50 \mathrm{~m}$ a.s.l. and are located around the coast in the north part and along the Solo River in the south part. The area with an altitude above $100 \mathrm{~m}$ a.s.l.
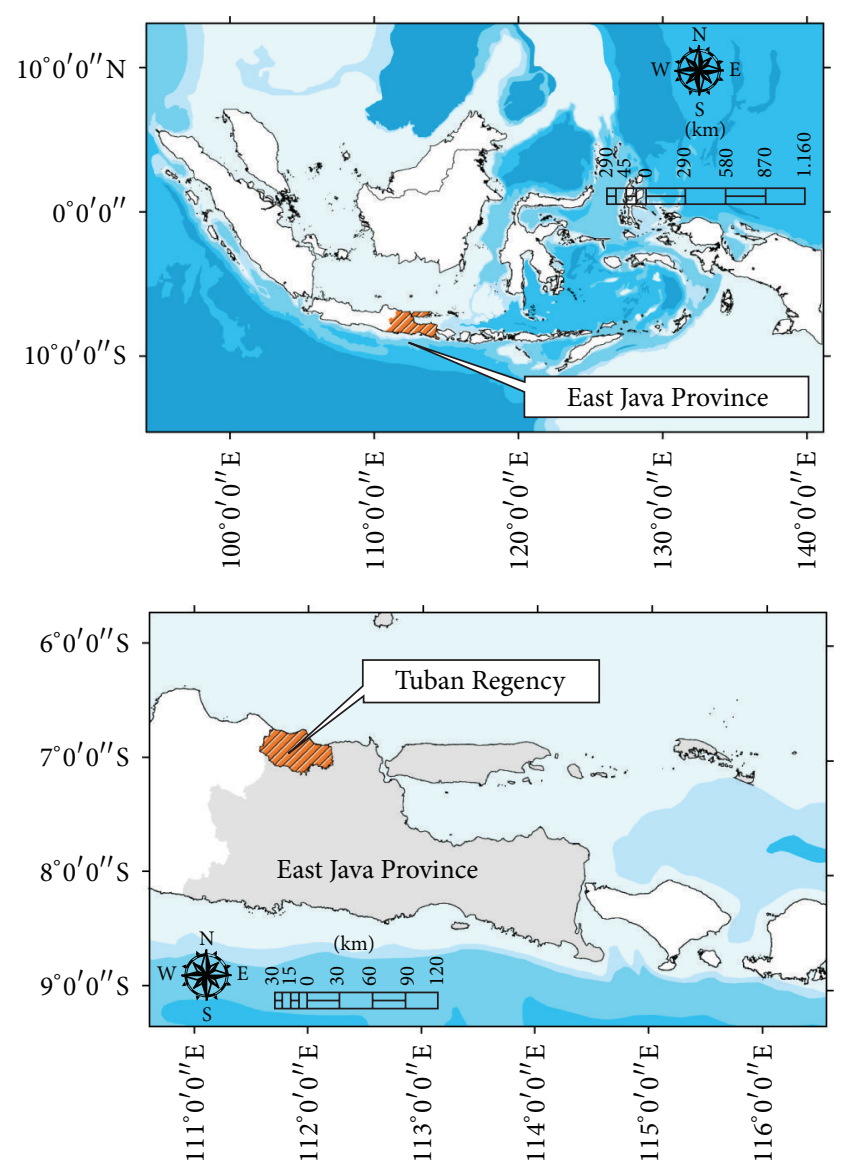

FIgURE 1: Study area of Tuban Regency, East Java.

is located at the centre of the region, extending from west to east $[11,20]$.

Observation from 1: 100,000 geological maps [21] showed that the study area was developed from sedimentary rock; the geological formations are generally carbonate rocks. Volcanic rock formations also appear and are formed by quaternary to tertiary Oligocene rocks. The northern part of the region, the coastal area, was developed from alluvium material.

2.2. General Analysis Procedure. Two groups of evaluation methods were used, namely, land suitability evaluation and land availability evaluation (Figure 2). Land suitability evaluation was conducted using the MCA procedure. Four parameters were used, consisting of eight criteria; each criterion consisted of several subcriteria. The land availability was analysed using the spatial overlay of two parameters: forest area status designation (FASD) and land allocation in spatial patterns of regional official land use plan (SP-ROLUP). The results of land suitability and land availability evaluations were then analysed to obtain suitable land which is available for agriculture.

\subsection{Land Suitability Evaluation}

\subsubsection{Criteria Used and Data Sources}

Land Parameter. The land parameters used in this research consist of soil class and land capability class as criteria. Soil 


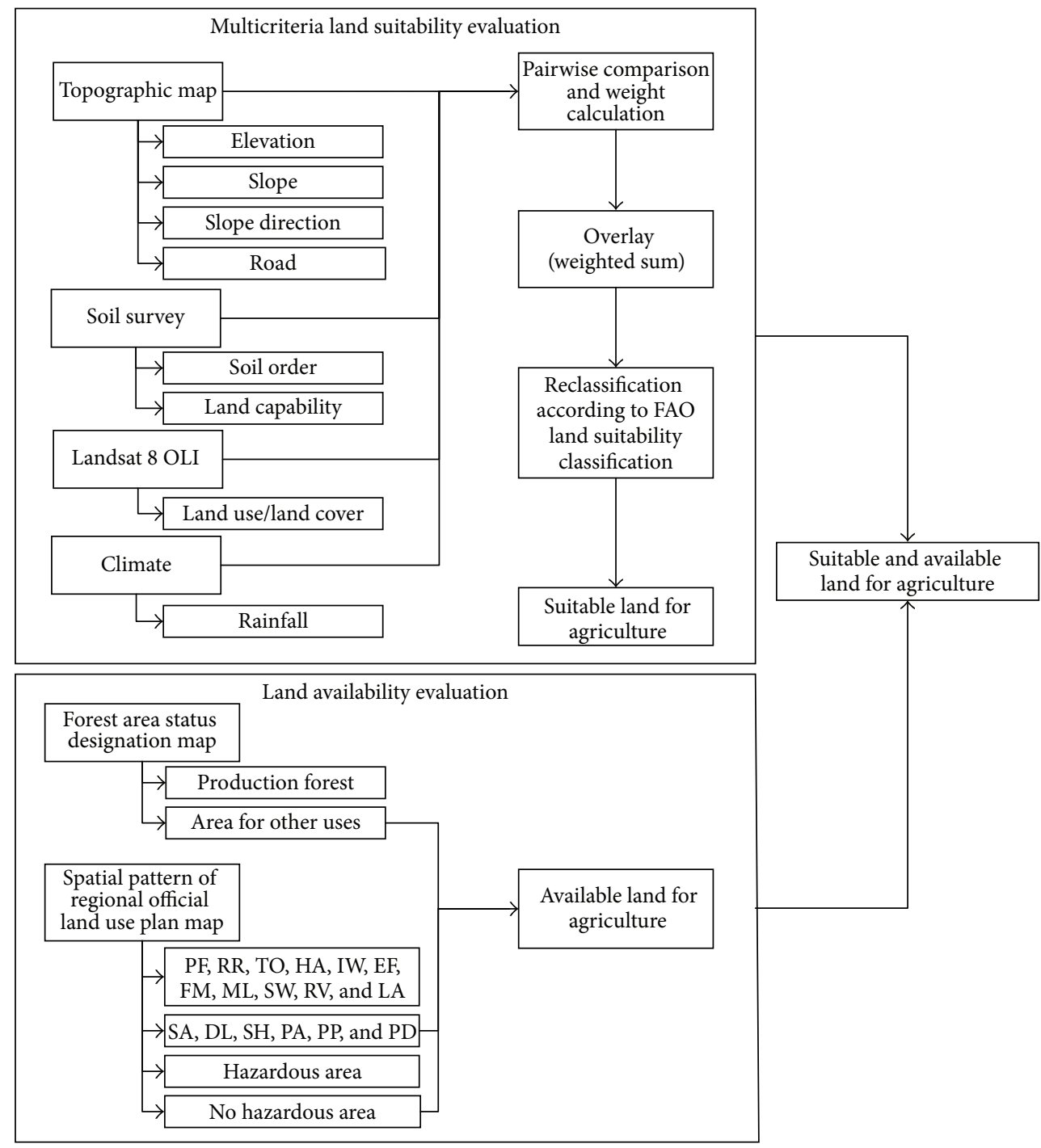

Figure 2: Procedure followed in generating suitable and available land for agriculture in Tuban Regency. Note: abbreviations used in spatial pattern of regional official land use plan (SP-ROLUP): PF: production forests, RR: reserved land for residential, PA: paddy fields, PP: paddy field/ponds, SA: sustainable agricultural land, DL: dryland farming, SH: shrub, TO: tourism, HA: harbour, IW: industry and warehouse, EP: electric power, FM: fish market, ML: mining land, SW: swamps, PD: ponds, RV: rivers, and LA: lake.

class data was derived from a soil survey in 2014, resulting soil map at scale of $1: 25,000[11,20]$. The map presents five soil orders [22]: Alfisols, Entisols, Inceptisols, Ultisols, and Vertisols (Figure 3(a) and Table 1). Inceptisols occupy the largest area, covering $83,152.9$ ha (45.2\% of the region). Alfisols are also quite widely spread, covering 41,967.5 ha (22.8\%). The other soils, Entisols, Vertisols, and Ultisols, represent less than $15 \%$ of the study area each [11].

Land capability was classified according to the USDA's land capability classification [23]. The soil in Tuban Regency ranges from class II to class VIII (Figure 3(b) and Table 1). Areas with a land capability which supports agricultural uses (classes I-IV) make up 78.3\% of the total land area, while the areas which should not be used for agricultural cultivation (classes V-VIII) made up 21.7\% of the total land area [11].
Topographic Parameter. The topographic parameter included elevation, slope, and slope direction as criteria. All three criteria were taken from the Indonesian Topographic Map at a scale of 1:25,000, produced by the Indonesian Geospatial Information Agency [11]. Elevation, slope, and slope direction maps were made from this topographic map using the modules available in the ArcGIS 10.2 software (Figures 3(c), $3(\mathrm{~d})$, and 3(e) and Table 1). According to slope, the dominant landform varies from undulating (3-8\%), gently sloping (8$15 \%)$, and hilly (15-25\%). This relates to elevation, which is dominated by three altitude classes, from $10 \mathrm{~m}$ to $500 \mathrm{~m}$ a.s.l. For slope direction, slopes facing north and south are dominant, followed by slopes facing east and west.

Ease of Management Parameter. Two criteria used were land use/land cover and accessibility. The land use/land cover 

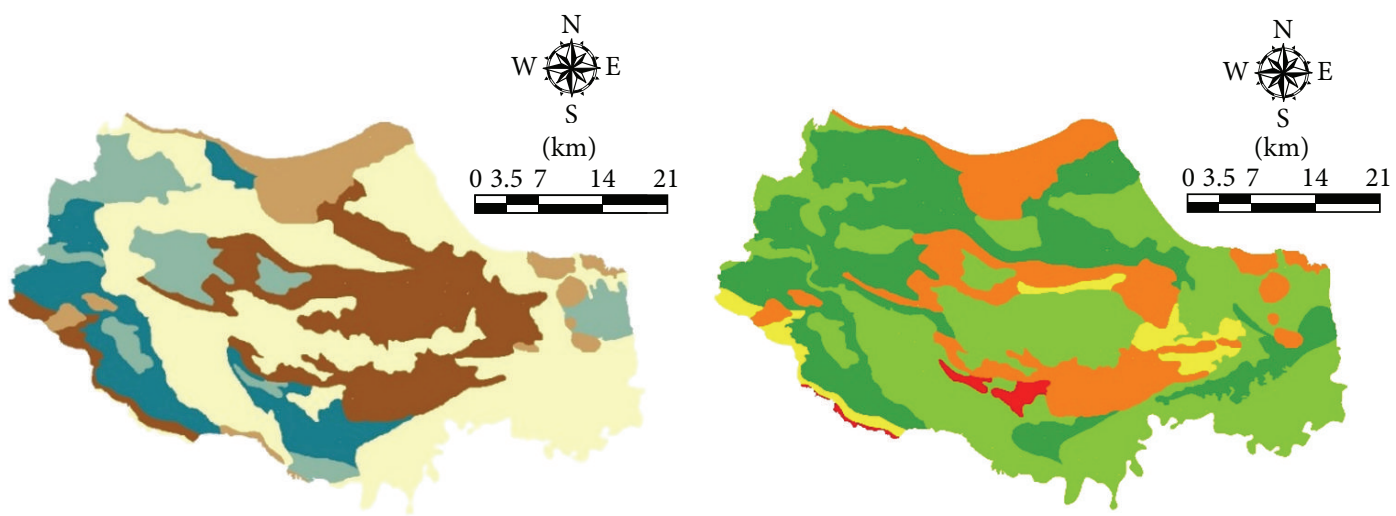

Soil order

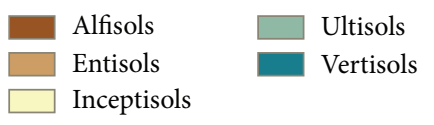

(a)

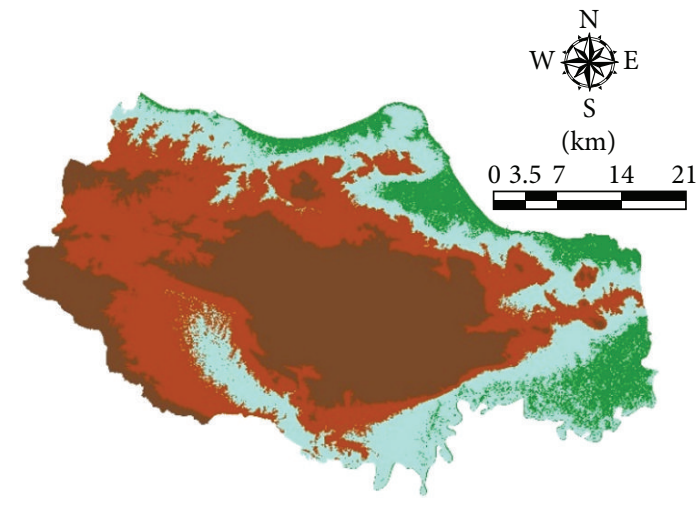

(c)

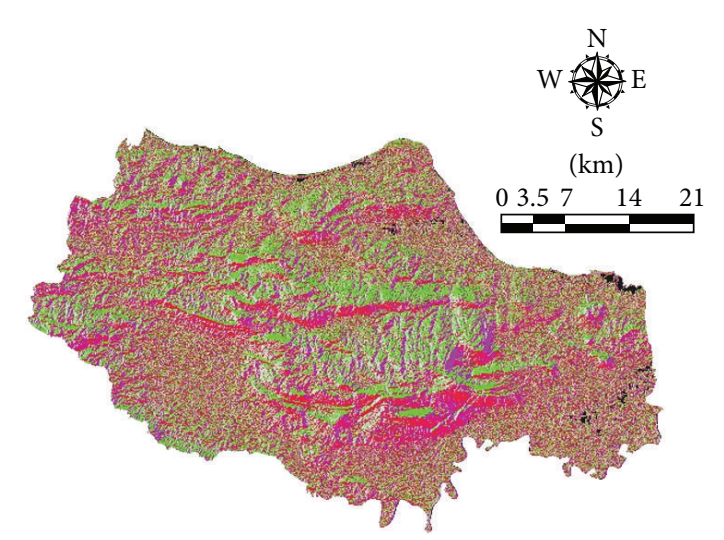

Slope direction

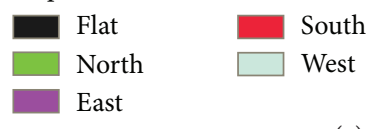

(e)

Land capability class

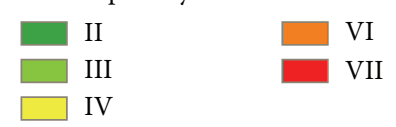

(b)

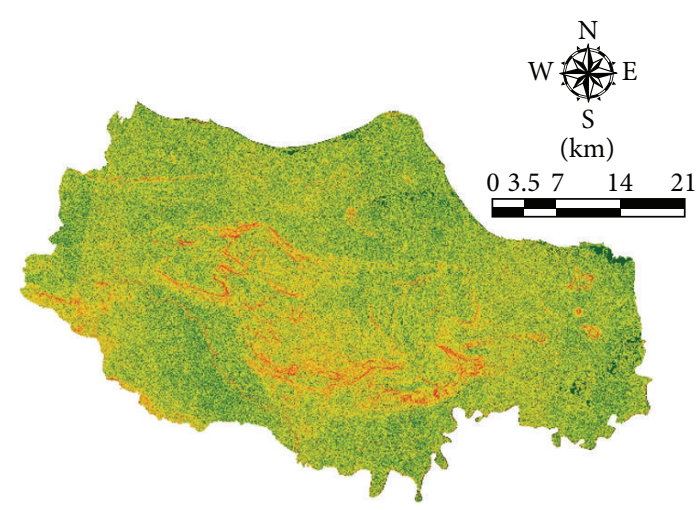

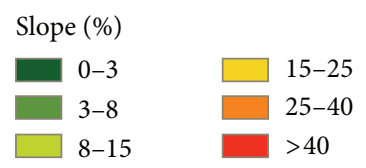

(d)

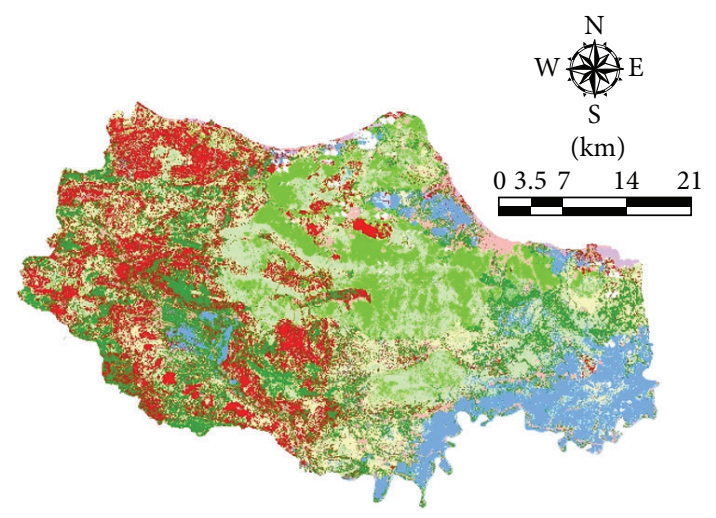

Land use/land cover

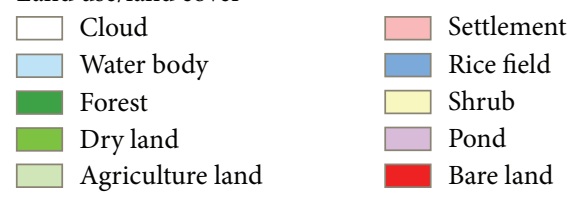

(f)

FIgure 3: Continued. 


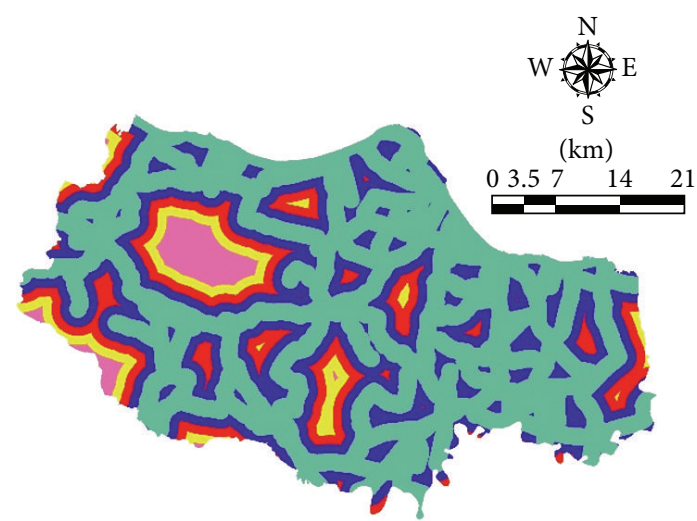

Distance to main road (meters)

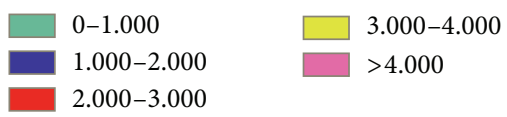

(g)

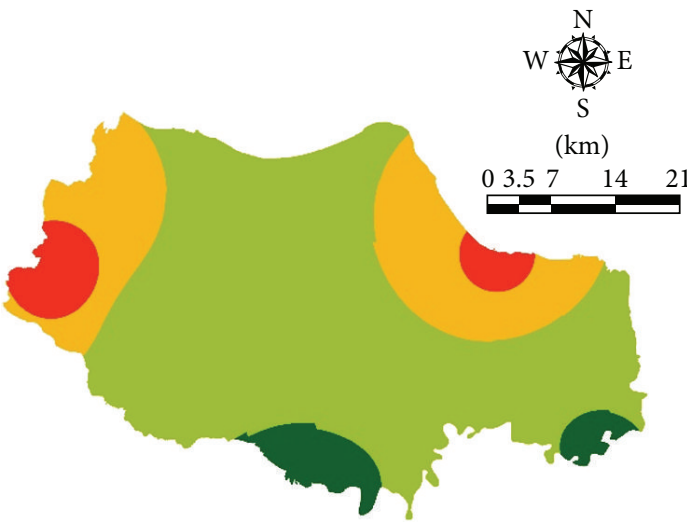

Rainfall (mm/year)
$1200-1400$
$1400-1600$

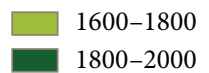

(h)

FIGURE 3: Criteria used for land suitability analysis in Tuban Regency: (a) soil order $^{1}$, (b) land capability class ${ }^{1}$, (c) elevation ${ }^{2},(\mathrm{~d})$ slope $^{1,2}$, (e) slope direction ${ }^{2}$, (f) land use/land cover ${ }^{1}$, (g) distance to main road ${ }^{2}$, and (h) rainfall ${ }^{2}$ (source of figures: ${ }^{1}$ [11]; ${ }^{2}$ analysis for this paper).

criteria were obtained from analysis using the Landsat 8 OLI imagery from the year 2013 [11] (Figure 3(f) and Table 1). Image interpretation was done by supervised classification using the ERDAS Imagine software, followed by field checks. Interpretation of the Landsat 8 OLI imagery produced 10 kinds of land use/land cover based on national standards classification [24]. The main land use/land cover in Tuban Regency regarding its area coverage are agricultural land, forest, open land, shrubs, and paddy fields. Dry land agriculture as well as residential areas occupies also a fairly wide area [11]. The accessibility was represented by the distance to a main road, obtained from the Indonesian Topographic Map of 1:25,000 (Figure 3(g) and Table 1).

Climatic Parameter. Climatic parameter considered in this study was the rainfall. Rainfall data were taken from interpolation of 35 rainfall stations in East Java Province, interpolated using geostatistical method. Spatial overlay with the administrative map of Tuban Regency was then done in order to obtain a rainfall map of Tuban Regency (Figure 3(h) and Table 1).

\subsubsection{Weighting of Criteria and Scoring of Subcriteria}

Weighting of Criteria. All of the spatial data were classified and weighted according to their contribution relative to agriculture to enable the creation of a suitability map for general agriculture (Figure 2). For weighting, expert consultation was conducted, for which eight experts were involved. Weighting was performed using AHP [25]. In this method, a pairwise comparison was done to obtain the relative importance of criteria considered. The ratings were derived from a nineinterest scale, with a value from 1 to 9 (Table 2) [7, 25].

Scoring. The scores were given according to the contribution of each subcriterion to agriculture; the score ranges from
0 to 10 . High scores were given to the subcriteria that are considered the most important for agriculture, while low scores were given to the least influential subcriteria [6-8]. For some subcriteria, a score of 0 was given as a constraint, indicating that it is not suitable for agriculture. Scoring was done by experts' consensus.

2.3.3. Land Suitability Map. After the criteria weights and the subcriteria scores were appointed to the related layers in the ArcGIS 10.2 environment, raster maps were overlaid using the weighted sum overlay analysis and an agricultural land suitability map was generated. The weights of the criteria were multiplied with the score of the subcriteria; this multiplication was performed in raster format on the map. The result was then reclassified using equal distances as four classes of suitability [2]: highly suitable (S1), moderately suitable (S2), marginally suitable (S3), and not suitable (N), according to the following formula $[7,26]$ :

$$
\mathrm{LS}=\sum_{i=1}^{n} w_{i} s_{i}
$$

where LS is land suitability; $w_{i}$ is weight of land suitability criteria; $s_{i}$ is score of subcriteria $i$; and $n$ is number of land suitability classes.

2.4. Land Availability Evaluation. Two sets of spatial data were used for the land availability analysis: the spatial data from the FASD map at a scale of 1:250,000 (Figure 4(a)) $[11,12,27]$ and the spatial data from SP-ROLUP map of Tuban Regency at a scale of 1:25,000 (Figure 4(c)) [11, 13]. In the FASD map, various states of forest areas are presented, including information about the different areas that allow for cultivation. The SP-ROLUP of Tuban Regency is an official document where land has been officially allocated 

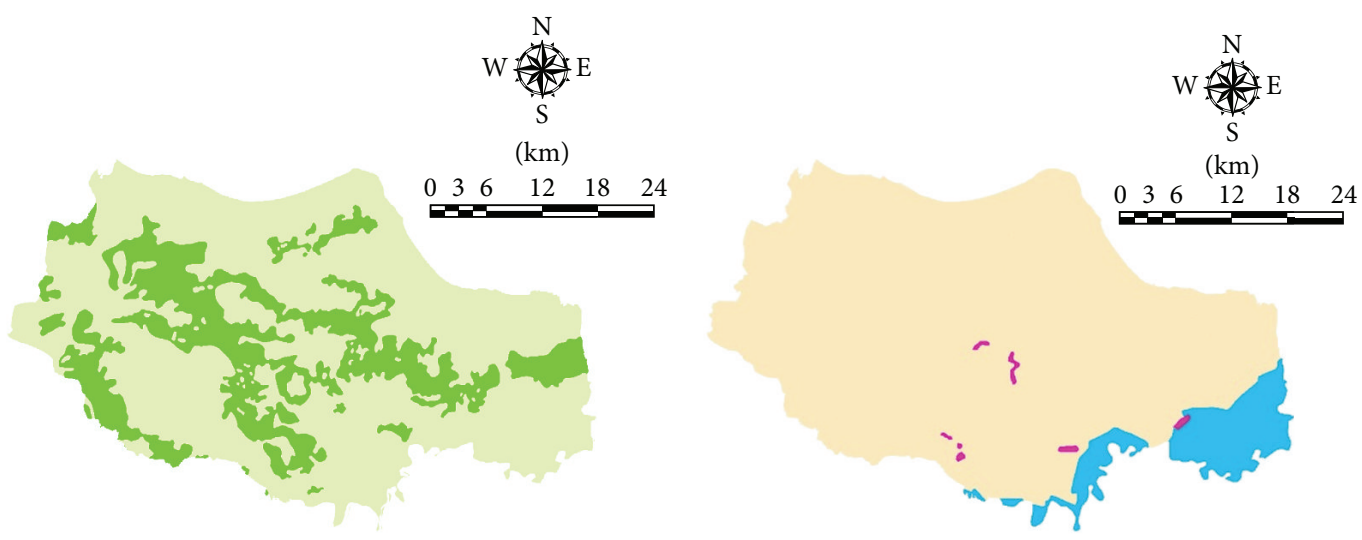

Forest status

Production forest Area for other uses
Hazardous area

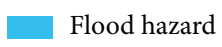

Landslide hazard
No hazard

(a)

(b)

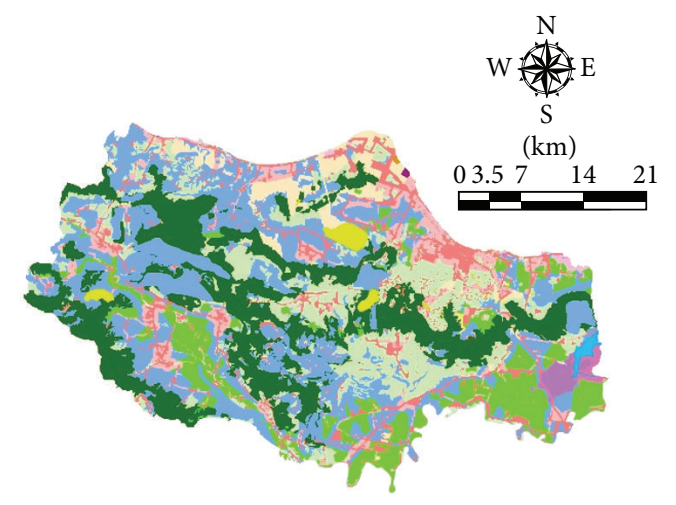

Spatial pattern of regional official land use plan

\begin{tabular}{ll}
\hline Production forest & Fish market \\
$\square$ Industry and warehouse & Swamp \\
$\square$ Reserved land for residential & $\square$ Rice field \\
$\square$ Sustainable agriculture land & Rice field/pond \\
$\square$ Tourism & $\square$ Shrub \\
$\square$ Harbour & $\square$ River \\
Settlement & $\square$ Pond \\
$\square$ Mining land & $\square$ Dry land farming \\
Electric power & $\square$ Lake
\end{tabular}

(c)

FIGURE 4: Maps used for analysis of land availability: (a) FASD map ${ }^{1,3}$, (b) flood hazard and landslide hazard presented in SP-ROLUP ${ }^{2}$, and (c) land allocation in SP-ROLUP map $^{2,3}$ (source of figures: ${ }^{1}[12] ;{ }^{2}[13] ;{ }^{3}[11]$ ).

for different uses. From the SP-ROLUP map, the areas of flood hazard and landslide hazard (16,387.3 ha and 843.1 ha, resp.) [13] were also used as a constraint in the preparation of land availability map, assuming that areas with flood and landslide hazard are deemed as unavailable for agriculture (Figure 4(b)).

\section{Results}

3.1. Weights of Criteria and Scores of Subcriteria. The pairwise comparisons are presented so that the value of 9 indicates that the line is relatively more important than the column, while the value of one-ninth shows that the line has significantly less importance than the column (Table 3 ) $[6,20,25,28]$. The results indicated that the consistency ratio (CR) was 0.04 . This value was well within the ratio of being equal to or less than 0.10 [25].

The scoring of each subcriterion is shown in Table 4. When evaluating soil orders, a score of 10 was given to Inceptisols, which are soil which has a high natural fertility [22]. A score of 8 was given to Entisols which are young soils [22] that have a high fertility as well, but they are 
TABLE 1: Distributions of the criteria and subcriteria in the study area of Tuban Regency.

\begin{tabular}{|c|c|c|c|c|}
\hline \multirow{2}{*}{ Parameter } & \multirow{2}{*}{ Criteria } & \multirow{2}{*}{ Subcriteria } & \multicolumn{2}{|c|}{ Area } \\
\hline & & & ha & $\%$ \\
\hline \multirow{10}{*}{ Land } & \multirow{5}{*}{ Soil order ${ }^{1}$} & Alfisols & $41,967.5$ & 22.8 \\
\hline & & Entisols & $15,364.6$ & 8.4 \\
\hline & & Inceptisols & $83,152.9$ & 45.2 \\
\hline & & Ultisols & $21,286.1$ & 11.6 \\
\hline & & Vertisols & $22,223.6$ & 12.1 \\
\hline & \multirow{5}{*}{ Land capability ${ }^{1}$} & II & $55,089.3$ & 29.9 \\
\hline & & III & $81,601.8$ & 44.4 \\
\hline & & IV & $7,862.5$ & 4.3 \\
\hline & & VI & $37,269.8$ & 20.3 \\
\hline & & VIII & $2,171.3$ & 1.2 \\
\hline \multirow{16}{*}{ Topography } & \multirow{5}{*}{ Elevation $^{2}$ (m a.s.l.) } & $0-10$ & $18,872.2$ & 10.3 \\
\hline & & $10-40$ & $44,087.8$ & 24.0 \\
\hline & & $40-100$ & $61,829.0$ & 33.6 \\
\hline & & $100-500$ & $59,204.9$ & 32.2 \\
\hline & & $>500$ & 0.7 & 0.0 \\
\hline & \multirow{6}{*}{ Slope $^{1}(\%)$} & $0-3$ & $16,882.3$ & 9.2 \\
\hline & & $3-8$ & $50,111.8$ & 27.2 \\
\hline & & $8-15$ & $68,115.5$ & 37.0 \\
\hline & & $15-25$ & $37,603.9$ & 20.4 \\
\hline & & $25-40$ & $9,296.6$ & 5.1 \\
\hline & & $>40$ & $1,984.6$ & 1.1 \\
\hline & \multirow{5}{*}{ Slope direction $^{2}$} & Flat & $2,270.8$ & 1.2 \\
\hline & & North & $56,121.9$ & 30.5 \\
\hline & & East & $39,109.1$ & 21.3 \\
\hline & & South & $51,265.9$ & 27.9 \\
\hline & & West & $35,227.0$ & 19.2 \\
\hline \multirow{15}{*}{ Ease of management } & \multirow{10}{*}{ Land use/land cover ${ }^{1}$} & Cloud & $2,190.1$ & 1.2 \\
\hline & & Water body & 928.7 & 0.5 \\
\hline & & Forest & $36,648.3$ & 19.9 \\
\hline & & Dry land & $19,489.6$ & 10.6 \\
\hline & & Agricultural land & $37,908.5$ & 20.6 \\
\hline & & Settlement & $11,140.4$ & 6.1 \\
\hline & & Paddy field & $21,192.8$ & 11.5 \\
\hline & & Shrub & $22,172.9$ & 12.1 \\
\hline & & Pond & 941.2 & 0.5 \\
\hline & & Bare land & $31,382.1$ & 17.1 \\
\hline & \multirow{5}{*}{ Distance $^{2}$ to road (m) } & $0-1,000$ & $106,421.4$ & 57.8 \\
\hline & & $1,000-2,000$ & $44,862.7$ & 24.4 \\
\hline & & $2,000-3,000$ & $18,735.5$ & 10.2 \\
\hline & & $3,000-4,000$ & $7,800.5$ & 4.2 \\
\hline & & $>4,000$ & $6,174.5$ & 3.4 \\
\hline \multirow{5}{*}{ Climate } & \multirow{5}{*}{ Rainfall $^{2}\left(\mathrm{~mm}\right.$ year ${ }^{-1}$ ) } & $1,200-1,400$ & $10,168.7$ & 5.5 \\
\hline & & $1,400-1,600$ & $39,597.9$ & 21.5 \\
\hline & & $1,600-1,800$ & $124,159.0$ & 67.5 \\
\hline & & $1,800-2,000$ & $10,069.1$ & 5.5 \\
\hline & & Total & $183,994.6$ & 100.0 \\
\hline
\end{tabular}

Data source: ${ }^{1}[11] ;{ }^{2}$ analysis for this paper. 
TABLE 2: Rating for pairwise comparison [7, 25].

\begin{tabular}{lcccccccc}
\hline $1 / 9$ & $1 / 7$ & $1 / 5$ & $1 / 3$ & 1 & 3 & 5 & 7 & 9 \\
\hline Extreme & $\begin{array}{c}\text { Very strong } \\
\text { Less important }\end{array}$ & Strong & Moderate & Equal & Moderate & Strong & $\begin{array}{c}\text { Very strong } \\
\text { More important }\end{array}$ \\
\hline
\end{tabular}

TABLE 3: A pairwise comparison matrix for assessing the weight (relative importance) of criteria for land suitability for agriculture in Tuban Regency.

\begin{tabular}{|c|c|c|c|c|c|c|c|c|c|}
\hline & $\mathrm{SO}$ & LCC & ELE & SLP & $\mathrm{SD}$ & LU & DR & RF & Weight \\
\hline $\mathrm{SO}$ & 1 & 2 & 5 & 4 & 6 & 7 & 8 & 3 & 0.327 \\
\hline LCC & $1 / 2$ & 1 & 4 & 3 & 5 & 6 & 7 & 2 & 0.227 \\
\hline ELE & $1 / 5$ & $1 / 4$ & 1 & $1 / 2$ & 2 & 3 & 4 & $1 / 3$ & 0.073 \\
\hline SLP & $1 / 4$ & $1 / 3$ & 2 & 1 & 3 & 4 & 5 & $1 / 2$ & 0.108 \\
\hline SD & $1 / 6$ & $1 / 5$ & $1 / 2$ & $1 / 3$ & 1 & 2 & 3 & $1 / 4$ & 0.050 \\
\hline LU & $1 / 7$ & $1 / 6$ & $1 / 3$ & $1 / 4$ & $1 / 2$ & 1 & 2 & $1 / 5$ & 0.034 \\
\hline DR & $1 / 8$ & $1 / 7$ & $1 / 4$ & $1 / 5$ & $1 / 3$ & $1 / 2$ & 1 & $1 / 6$ & 0.024 \\
\hline $\mathrm{RF}$ & $1 / 3$ & $1 / 2$ & 3 & 2 & 4 & 5 & 6 & 1 & 0.157 \\
\hline
\end{tabular}

SO: soil order; LCC: land capability class; ELE: elevation; SLP: slope; SD: slope direction; LU: land use/land cover; DR: distance to road; RF: rainfall. Max eigenvalue $(\gamma \max )=8.422770477 ; n=8$; consistency index $(\mathrm{Ci})=(\gamma \max -n) /(n-1)=0.060395782$; random index $(\mathrm{Ri})=1.41$; consistency ratio $(\mathrm{Cr})=$ $\mathrm{Ci} / \mathrm{Ri}=0.042833888$.

not mature enough and thus they can be considered less fertile than Inceptisols. A score of 6 was given to Vertisols, which are soils that have good chemical fertility but they are often constrained by poor physical properties with respect to their high clay content [22]. A score of 4 was given to Alfisols, old soils that have sufficiently high $\mathrm{pH}$ so that they have sufficiently high nutrient availability, while a score of 2 was given to Ultisols, which are old soils; they have acidity constraints and high exchangeable aluminium [22]. Agriculture is only permitted on land capability class I to class IV [23]; therefore, the highest to lowest scores were given to class I to IV land, and scores were $10,8,6$, and 4, respectively. For land of class $\mathrm{V}$ and more a score of 0 was given; they become constraints because they are not permitted to be used for agriculture [11, 23].

For elevation, the lowlands are more desirable for agriculture and more suitable for the cultivation of various crops such as paddy; thus, a higher score was given. The higher the elevation, the lower the suitability for many crops, although of course there are still many plants that are more suitable at high altitudes. Slopes are very influential for agriculture. In terms of ease of processing and low erosion, flat land is better and so a score of 10 was given. According to Law number 26 of 2007 on Spatial Planning which is applicable in Indonesia, land with slopes $>40 \%$ is protected and prohibited for agricultural uses, so a score of 0 was given. For slope direction, flat land and land facing east toward the rising sun are more suitable for agriculture, and so a high score was given to land with these slopes. Slope direction is associated with several properties, including exposure to sunlight, drying winds, and rainfall, which determine the different levels of suitability for agriculture.

In terms of actual land use/land cover, the highest score was given to actual agricultural land and paddy fields. For some land uses which are prohibited for agricultural use such as water bodies and settlements, a score of 0 was given as a constraint. The accessibility valuation was set by giving out higher scores to lands that were closer to the road; this was for reasons of ease of access, including better access to agricultural inputs and production transport [29]. The distance attributed was adapted according to the field conditions. It should be noted that there was no area that was given a score of 0 because almost all areas in Java Island are relatively accessible.

In terms of rainfall, a higher score was given to high intensity rainfall due to its implication for water sufficiency for agriculture. In this region, the whole climate range remained suitable for agriculture; therefore, no extreme scores were given, because of either too high or too low rainfall intensity.

3.2. Land Suitability. Of the whole Tuban Regency, most of the area is suitable for agriculture (Figure 5 and Table 5). The suitable land for agriculture in the region includes $166,916.3$ ha or $90.7 \%$ of the entire area of the regency which is $183,994.6 \mathrm{ha}$. Of this suitable land, the majority $(33.1 \%)$ is land that is highly suitable (S1) for agriculture. There is only $9.3 \%$ of the area of the region where land was classified as not suitable for agriculture.

3.3. Suitable Land Available according to Forest Area Status Designation (FASD). In Indonesia, the land utilization for any cultivation is restricted by Law number $41 / 1999$ on Forestry. Land utilization for cultivation (residential, industrial, and others, including agriculture) can only be done outside the FASD, in the so-called area for other uses (AOU). Based on the FASD, Tuban Regency area can be classified into two classes, namely, production forest area and AOU. Production forest areas occupy an area of 51,995 ha, which represents $26.5 \%$ of the entire study area, while the other $74.5 \%$ has the status of AOU. Overlaying the land suitability 
TABLE 4: Scores of the subcriteria used in Tuban Regency.

\begin{tabular}{|c|c|c|c|c|}
\hline Parameter & Criteria & Weight & Subcriteria & Score \\
\hline \multirow{10}{*}{ Land } & \multirow{5}{*}{ Soil order } & \multirow{5}{*}{0.327} & Inceptisol & 10 \\
\hline & & & Entisol & 8 \\
\hline & & & Vertisol & 6 \\
\hline & & & Alfisol & 4 \\
\hline & & & Ultisol & 2 \\
\hline & \multirow{5}{*}{ LCC } & \multirow{5}{*}{0.227} & I & 10 \\
\hline & & & II & 8 \\
\hline & & & III & 6 \\
\hline & & & IV & 4 \\
\hline & & & V-VIII & 0 \\
\hline \multirow{16}{*}{ Topographic } & \multirow{6}{*}{ Elevation } & \multirow{6}{*}{0.073} & $0-10$ & 10 \\
\hline & & & $10-40$ & 8 \\
\hline & & & $40-100$ & 6 \\
\hline & & & $100-500$ & 4 \\
\hline & & & $500-2,000$ & 2 \\
\hline & & & $>2,000$ & 0 \\
\hline & & \multirow{6}{*}{0.108} & $0-3$ & 10 \\
\hline & \multirow{5}{*}{ Slope } & & $3-8$ & 8 \\
\hline & & & $8-15$ & 6 \\
\hline & & & $15-25$ & 4 \\
\hline & & & $25-40$ & 2 \\
\hline & & & $>40$ & 0 \\
\hline & \multirow{4}{*}{ Slope direction } & \multirow{4}{*}{0.050} & Flat, east & 10 \\
\hline & & & West & 8 \\
\hline & & & North & 6 \\
\hline & & & South & 4 \\
\hline \multirow{11}{*}{ Ease of management } & \multirow{6}{*}{ Land use/land cover } & \multirow{6}{*}{0.034} & Agricultural land, paddy field & 10 \\
\hline & & & Dry land & 8 \\
\hline & & & Bare land & 6 \\
\hline & & & Shrub & 4 \\
\hline & & & Forest & 2 \\
\hline & & & Cloud, water body, settlement, pond & 0 \\
\hline & \multirow{5}{*}{ Infrastructure } & \multirow{5}{*}{0.024} & $0-1,000$ & 10 \\
\hline & & & $1,000-2,000$ & 8 \\
\hline & & & $2,000-3,000$ & 6 \\
\hline & & & $3,000-4,000$ & 4 \\
\hline & & & $>4,000$ & 2 \\
\hline \multirow{4}{*}{ Climate } & \multirow{4}{*}{ Rainfall } & \multirow{4}{*}{0.157} & $1,200-1,400$ & 4 \\
\hline & & & $1,400-1,600$ & 6 \\
\hline & & & $1,600-1,800$ & 8 \\
\hline & & & $1,800-2,000$ & 10 \\
\hline
\end{tabular}

map with map of FASD leaves an area of 155,527 ha (84.6\%) which is suitable for agriculture at any different suitability (S1 to S3) outside FASD (Figure 6(a) and Table 6). The unsuitable land outside FASD was $16,988.7$ ha. An area of 11,479 ha was so unavailable for agriculture because it was inside FASD, regardless of its suitability.
3.4. Suitable Land Available according to Spatial Pattern of Regional Official Land Use Plan (SP-ROLUP). Land use planning in Indonesia should conform to Law number 26 of 2007 on Spatial Planning. Spatial land allocation of Tuban Regency consists of land for production forests, reserved land for residential, paddy fields, sustainable agriculture, 
TABLE 5: Distribution area of suitable land for agriculture in Tuban Regency.

\begin{tabular}{lcc}
\hline \multirow{2}{*}{ Suitability level } & Total area classified by the suitability \\
& ha & $\%$ \\
\hline Highlysis & 33.1 \\
Moderately suitable & $50,812.3$ & 29.3 \\
Marginally suitable & $52,866.8$ & 28.4 \\
Not suitable & $17,078.3$ & 9.3 \\
\hline Total & $183,994.6$ & 100.0 \\
\hline
\end{tabular}

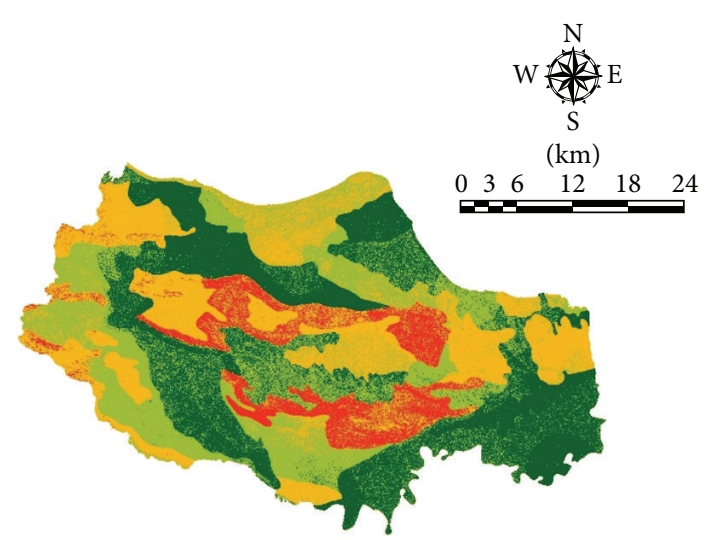

$\begin{array}{ll}\text { Highly suitable } & \text { Marginally suitable } \\ \square \text { Moderately suitable } & \text { Not suitable }\end{array}$

FIgURE 5: Suitable land for agriculture in Tuban Regency.

tourism, housing, industry and warehouse, plantation, fish landing centres, ports, mines, swamps, ponds, and rivers. Of the allocation in the SP-ROLUP, land which is available for agriculture includes sustainable agricultural land, paddy fields, and ponds. Calculating, from the 183,994.6 ha of study area, the land which is available for agricultural use according to SP-ROLUP (i.e., inside the area permitted for agriculture use) and free from flood and landslide hazards, 34,496 ha or $18.7 \%$ of the total area is found (Figure 6(b) and Table 6), while $16,988.7$ ha is not available.

3.5. Final Suitable and Available Land for Agriculture. The overlay done between the FASD-based suitability map and the SP-ROLUP-based suitability map gives the suitable land which is available for agriculture. The final results showed that the total area of suitable land which is available for agriculture was $33,385.3$ ha or $18.2 \%$ of the total study area. This comprises $6.4 \%$ of highly suitable land, $5.4 \%$ of moderately suitable land, and $6.4 \%$ of marginally suitable land (Figure 7 and Table 6).

\section{Discussion}

The results of the analysis showed that the unsuitable area corresponds with high slopes falling under land capability class
V or more. Our results which indicate the high percentage of suitable land for agriculture in Tuban Regency confirm the known fact [30] that the study area has fertile soil.

The results of the analysis showed that the area which is suitable and available for agriculture remains $18.2 \%$. In the context of SP-ROLUP, it is logical that some of the land had to be allocated to the various needs, as agriculture is just one of the various land utilizations. Regarding the analysis results in this regency, it can be stated that the suitable lands which are available for agriculture are not many. In the context of the country, this fact was also found in other areas in Java Island $[7,14]$. It is so becoming somewhat ironic and even worrying that the availability of food in the country with the fourth largest population in the world depends on an island that constitutes less than $7 \%$ of the state territory, of which less than a fifth is suitable and available for agriculture.

For the case of Tuban Regency, a more detailed analysis can be conducted by viewing the suitable and available land which is actually being used for agriculture. Based on the data of land use/land cover resulting from imagery interpretation and field survey results (Table 1), it can be stated that the land use/land cover that has actually been used for agriculture consists of paddy fields (an area of $21,192.8 \mathrm{ha}$ ), agricultural land (an area of 37,908.5 ha), and ponds (an area of $941.2 \mathrm{ha}$ ). This agricultural land includes state plantations, smallholdings plantations, and ponds that are permanent land utilization. Overlaying the suitable and available land results from the final analysis with land actually used for agriculture leaves $11,123.2$ ha or $6.7 \%$ of the total suitable and available land area for agriculture. This area constitutes the possibility for agricultural expansion when necessary. This expansion possibility constitutes a very small area considering the rapid growth of the population with its need for food as well as infrastructure.

These results reveal that there is no longer as much land available in the region which can be used for the development of agriculture, although the area has the fertile and suitable soil for agriculture. The expansion of paddy fields, for example, which is absolutely necessary because of the increasing population and its implications for increasing food demand, seems to be hard to accomplish. The implication is that the search for productive land outside Java Island is imperative.

This research is also intended to provide broader awareness to the stakeholders and policymakers in the country where the situation of land utilization in Java Island is completely serious. Although many parties claim to be aware of this situation, in reality many controversial policies continue to be enacted. An example is the policy actually applicable in Indonesia [31]. In this policy, the development of Indonesia is divided into six corridors of development, one of which is a corridor of Java Island whose main policy direction is to make Java Island the centre of industry and national services. Seeing that there is still a very high dependence in Indonesian food supply on the island of Java today, this policy is feared to accelerate the conversion of agricultural land into industrial land. The implication is the danger of food insecurity of Indonesia in the medium- and long-term, given that the development of the agricultural sector outside Java Island will still take time. Corrections to several current 
TABLE 6: Distribution area of suitable land which is available for agriculture in Tuban Regency.

\begin{tabular}{lcccccc}
\hline \multirow{2}{*}{ Suitability level } & \multicolumn{2}{c}{ Taking into account FASD } & \multicolumn{2}{c}{ Taking into account SP-ROLUP } & \multicolumn{3}{c}{ Taking into account FASD and SP-ROLUP } \\
& ha & $\%$ & ha & $\%$ & ha & \% \\
\hline Highly suitable & $59,350.0$ & 32.3 & $12,019.7$ & 6.5 & $11,764.4$ & 6.4 \\
Moderately suitable & $48,866.2$ & 26.6 & $10,388.0$ & 5.6 & $9,898.0$ & 5.4 \\
Marginally suitable & $47,310.8$ & 25.7 & $12,088.3$ & 6.6 & $11,722.9$ & 6.4 \\
Not suitable & $16,988.7$ & 9.2 & $16,988.7$ & 9.2 & $16,988.7$ & 9.2 \\
Not available & $11,479.0$ & 6.2 & $132,509.9$ & 72.0 & $133,620.6$ & 72.6 \\
\hline Total & $183,994.6$ & 100.0 & $183,994.6$ & 100.0 & $183,994.6$ & 100.0 \\
\hline
\end{tabular}

${ }^{1}$ The suitability was measured only for the area outside the forest area status designation (FASD), while the area inside the FASD is considered as unavailable.

${ }^{2}$ The suitability was measured inside the area permitted for agriculture (outside the area not permitted for agriculture, which is considered as unavailable) according to spatial pattern of regional official land use plan (SP-ROLUP) map.

${ }^{3}$ Combination of 1 and 2.
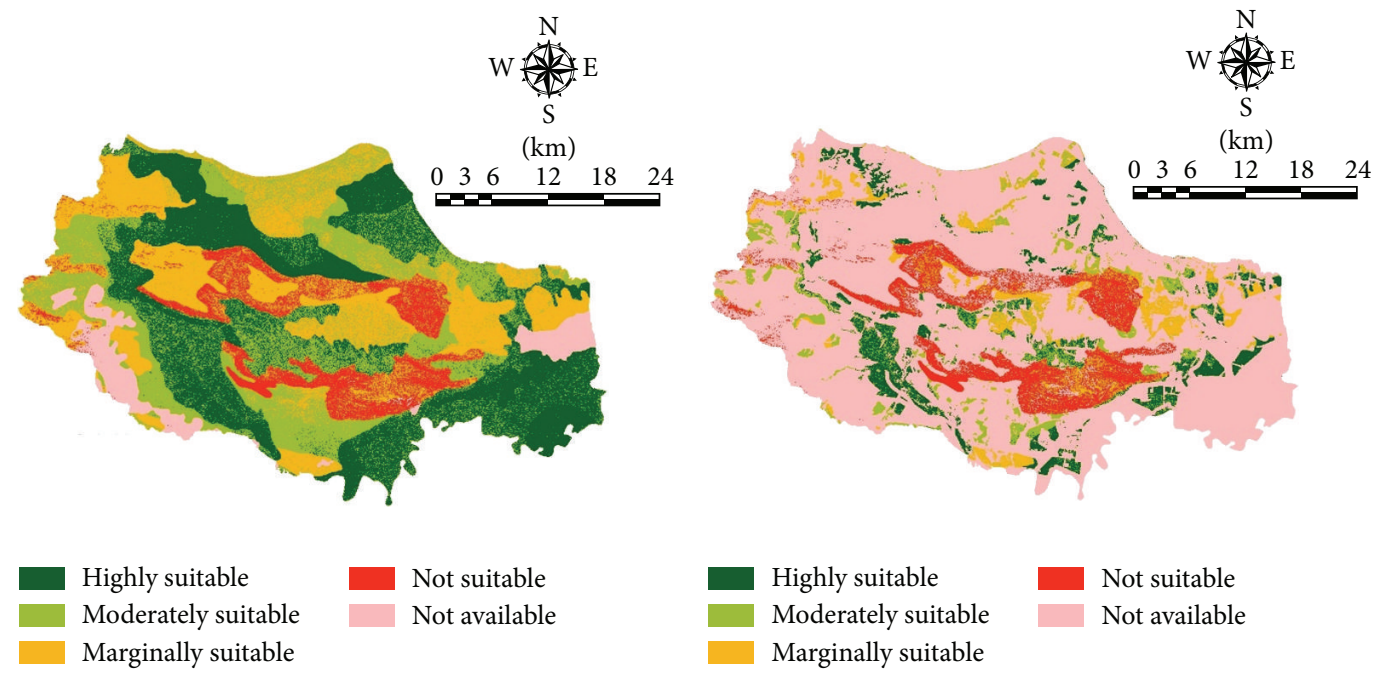

(a)

(b)

FIGURE 6: Land in Tuban Regency which is both suitable and available for agriculture, taking into account (a) FASD and (b) SP-ROLUP.

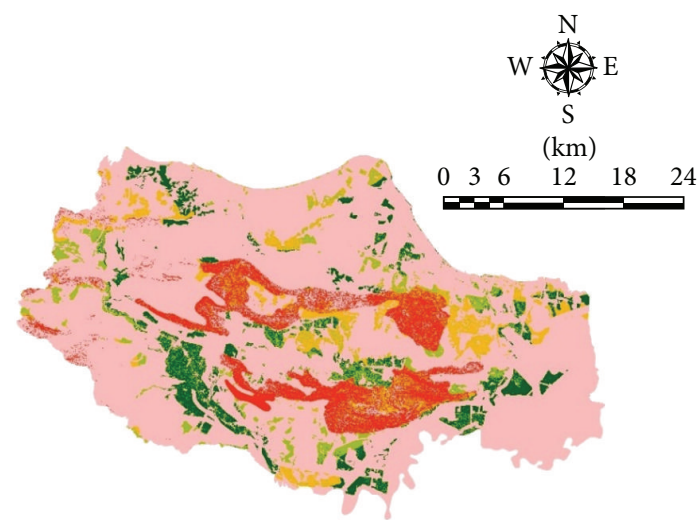

Not suitable

Not available

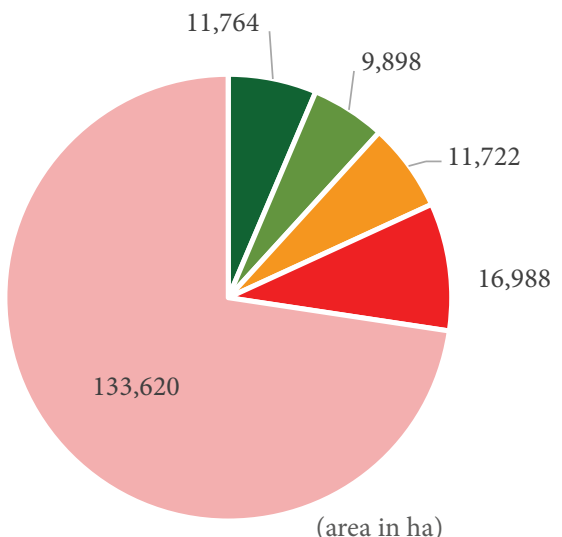

(area in ha)
Highly suitable

Moderately suitable

Marginally suitable

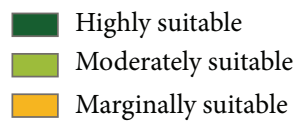

(a)

a)

(b)

FIGURE 7: Final map (a) and total area (b) of land which is suitable and available for agriculture in Tuban Regency when considering constraints from FASD and SP-ROLUP. 
government policies might be necessary in order to ensure future food security.

The necessity of taking into account the FASD map can be viewed from an environmental protection perspective. Although a large proportion of the land is suitable for agriculture, the area inside the FASD should not be used for agriculture. This regulation is necessary in order for Indonesian forests to remain sustainable [20, 32]. As is known, Indonesian forests are one of the largest and most biodiverse tracts of tropical rainforest in the world, hosting mega-biodiversity comparable to that of the Amazon in Brazil. In the context of environmental sustainability, land use planning for agriculture needs to follow regulations.

There are some limitations to the validity of this analysis which should be noted. Firstly, from the point of view of the methodology, the suitability analysis depended on the AHP result, which is highly dependent on experts' opinions. AHP has the advantages of decomposing issues so that complex problems can be structured; nevertheless, by its nature AHP is highly dependent on experts and as a result it is very subjective. Competent experts have been chosen for this study, and the AHP results have the consistency ratio required to be valid. Nevertheless, the subjective character of the method still needs to be noted. The second limitation to the validity of this suitability analysis lies on how the parameter and criteria are viewed upon. In reality, land suitability for agriculture should also consider social aspects. In this study, the social aspect is accommodated within the parameters of ease of management, which included criteria such as land use/land cover and distance from the road. However, there were many other aspects which should also be considered, such as labor availability. One of the obstacles to integrate more social aspects in this type of study is the difficulty in which to integrate social aspects into spatial representation. Consequently, other social aspects that are not explored during this study should be considered in further and other types of studies.

\section{Conclusion}

The analysis in this study showed the suitable land which is available for agriculture in a regency in Java Island, Indonesia's most fertile island. Land suitability analysis was conducted by integrating the main influential parameters for agriculture, which include soil class, land capability class, slope, elevation, slope direction, present land use, distance to road, and climate. Integration using MCA produced suitable land corresponding to $90.7 \%$ of the total land area in Tuban Regency. Analysis of the land availability then indicated that $18.2 \%$ of the area is suitable and available for agriculture. When considering the suitable land which is now used for agriculture, the development of agriculture in the region has only $6.7 \%$ of the land area in which to expand. The results of this analysis show the importance of seeking the allocation of land outside Java Island to anticipate the need for food in the area with a high population growth rate, as well as the development of policy in favour of agricultural development.

\section{Competing Interests}

The authors declare that there is no conflict of interests regarding the publication of this paper.

\section{Acknowledgments}

The authors acknowledge the Government of Tuban Regency for funding this research, in collaboration with Bogor Agricultural University.

\section{References}

[1] E. A. Law, E. Meijaard, B. A. Bryan, T. Mallawaarachchi, L. P. Koh, and K. A. Wilson, "Better land-use allocation outperforms land sparing and land sharing approaches to conservation in Central Kalimantan, Indonesia," Biological Conservation, vol. 186, pp. 276-286, 2015.

[2] Food and Agriculture Organization (FAO) of the United Nations, "A framework of land evaluation," FAO Soil Bulletin 6, FAO, Rome, Italy, 1976.

[3] P. Manna, A. Basile, A. Bonfante, R. De Mascellis, and F. Terribile, "Comparative land evaluation approaches: an itinerary from FAO framework to simulation modelling," Geoderma, vol. 150, no. 3-4, pp. 367-378, 2009.

[4] I. Pilvere, A. Nipers, and I. Upite, "Agricultural land utilization efficiency: the case of Latvia," International Journal of Trade, Economics and Finance, vol. 5, no. 1, pp. 65-71, 2014.

[5] Widiatmaka, A. Sutandi, A. Iswandi, U. Daras, M. Hikmat, and A. Krisnohadi, "Establishing land suitability criteria for cashew (Anacardium occidentale L.) in Indonesia," Applied and Environmental Soil Science, vol. 2014, Article ID 743194, 14 pages, 2014.

[6] H. Akinci, A. Y. Özalp, and B. Turgut, "Agricultural land use suitability analysis using GIS and AHP technique," Computers and Electronics in Agriculture, vol. 97, pp. 71-82, 2013.

[7] Widiatmaka, W. Ambarwulan, and Sudarsono, "Multicriteria decision-making for delineating agricultural land in Jakarta metropolitan area's hinterland: case study of Bogor Regency, West Java," Agrivita Journal of Agricultural Science, vol. 38, no. 2, pp. 105-115, 2016.

[8] J. Malczewski, "GIS-based multicriteria decision analysis: a survey of the literature," International Journal of Geographical Information Science, vol. 20, no. 7, pp. 703-726, 2006.

[9] B. Feizizadeh and T. Blaschke, "Land suitability analysis for Tabriz County, Iran: a multi-criteria evaluation approach using GIS," Journal of Environmental Planning and Management, vol. 56, no. 1, pp. 1-23, 2013.

[10] M. Tratnik, R. Franic, K. Svrznjak, and F. Basic, "Land rents as a criterion for regionalization-the case of wheat growing in Croatia," Land Use Policy, vol. 26, no. 1, pp. 104-111, 2009.

[11] Widiatmaka, W. Ambarwulan, M. Y. J. Purwanto, Y. Setiawan, and H. Effendi, "Land capability based environmental carrying capacity in Tuban, East Java," Jurnal Manusia dan Lingkungan, vol. 22, no. 2, pp. 247-259, 2015 (Indonesian).

[12] Ministry of Forestry, Decree of Minister of Forestry No. SK. 395/Menhut-II/2011 about Designation of Forest Area Status in East Java Province, Ministry of Forestry, Jakarta, Indonesia, 2011 (Indonesian). 
[13] Government of Tuban Regency, Regional Official Spatial Landuse Plan of Tuban Regency 2012-2032, Government of Tuban Regency, Tuban, Indonesia, 2012.

[14] Widiatmaka, W. Ambarwulan, I. Firmansyah, K. Munibah, P. B. K. Santoso, and Sudarsono, "Land suitability and dynamic system modelling to define priority areas of soybean plantation in paddy fields in Karawang, West Java," Agrivita Journal of Agricultural Science, vol. 36, no. 1, pp. 235-248, 2014.

[15] Indonesian Statistics, Indonesian Population According to Province 2010, 2010 (Indonesian), http://www.bps.go.id.

[16] Indonesian Statistics, Indonesian Population Projection 20102035, National Development Planning Agency, Indonesian Statistics, United Nations Population Fund, Jakarta, Indonesia, 2013.

[17] Indonesian Statistics, Statistics of Indonesia 2015, Indonesian Statistics Agency, Jakarta, Indonesia, (Indonesian).

[18] Indonesian Statistics, "Harvested Area-Productivity-Production Paddy Field of all Province," 2014 (Indonesian), https:// www.bps.go.id/.

[19] Statistic of Tuban Regency, Tuban Regency in Figures, Tuban East Java, Indonesian Statistic, 2012 (Indonesian).

[20] Widiatmaka, W. Ambarwulan, Y. Setiawan, M. Y. J. Purwanto, Taryono, and H. Effendi, "Land use planning for brackish water shrimp ponds in the North Coast of Tuban, Indonesia," Indonesian Journal of Geography, vol. 47, no. 2, pp. 193-210, 2015.

[21] Hartono and Suharsono, Geological Map of Tuban Sheet, Scale 1:100,000, Geological Center for Research and Development, Bandung, Indonesia, 1997 (Indonesian).

[22] Soil Survey Staff, Keys to Soil Taxonomy, United States Department of Agriculture, 2010.

[23] A. A. Klingebiel and P. H. Montgomery, Land Capability Classification, Agriculture Handbook No. 210, Soil Conservation Service, U.S. Department of Agriculture, Washington, DC, USA, 1961.

[24] Indonesian National Standard (INS), "Land cover classification," Indonesian National Standard 7645, INS, 2010 (Indonesian).

[25] T. L. Saaty, "Decision making with the analytic hierarchy process," International Journal of Service Sciences, vol. 1, no. 1, pp. 83-98, 2008.

[26] T. Cengiz and C. Akbulak, "Application of analytical hierarchy process and geographic information systems in land-use suitability evaluation: a case study of Dümrek village (Çanakkale, Turkey)," International Journal of Sustainable Development and World Ecology, vol. 16, no. 4, pp. 286-294, 2009.

[27] Ministry of Forestry, Regulation of Minister of Forestry of the Republic of Indonesia No.: P.50/Menhut-II/2009, Ministry of Forestry, Jakarta, Indonesia, 2009 (Indonesian).

[28] M. S. Hossain and N. G. Das, "GIS-based multi-criteria evaluation to land suitability modelling for giant prawn (Macrobrachium rosenbergii) farming in Companigonj Upazila of Noakhali, Bangladesh," Computers and Electronics in Agriculture, vol. 70, no. 1, pp. 172-186, 2010.

[29] O. Dilly and R. F. Hüttl, “Top-down and Europe-wide versus bottom-up and intra-regional identification of key issues for sustainability impact assessment," Environmental Science and Policy, vol. 12, no. 8, pp. 1168-1176, 2009.

[30] E. C. J. Mohr, F. A. Van Baren, and J. Van Schuylenborgh, Tropical Soils: A Comprehensive Study of Their Genesis, W. Van Hoeve Publishers, The Hague, The Netherlands, 3rd edition, 1972.
[31] Ministry of Economic Coordinating, Masterplan of Indonesian Economic Development Speed-Up, Ministry of Economic Coordinating, Jakarta, Indonesia, 2011 (Indonesian).

[32] Widiatmaka, W. Ambarwulan, A. Sutandi, K. Murtilaksono, K. Munibah, and U. Daras, "Suitable and available land for cashew (Anacardium occidentale L.) in the island of Lombok, Indonesia," Journal of Applied Horticulture, vol. 17, no. 2, pp. 129139,2015 

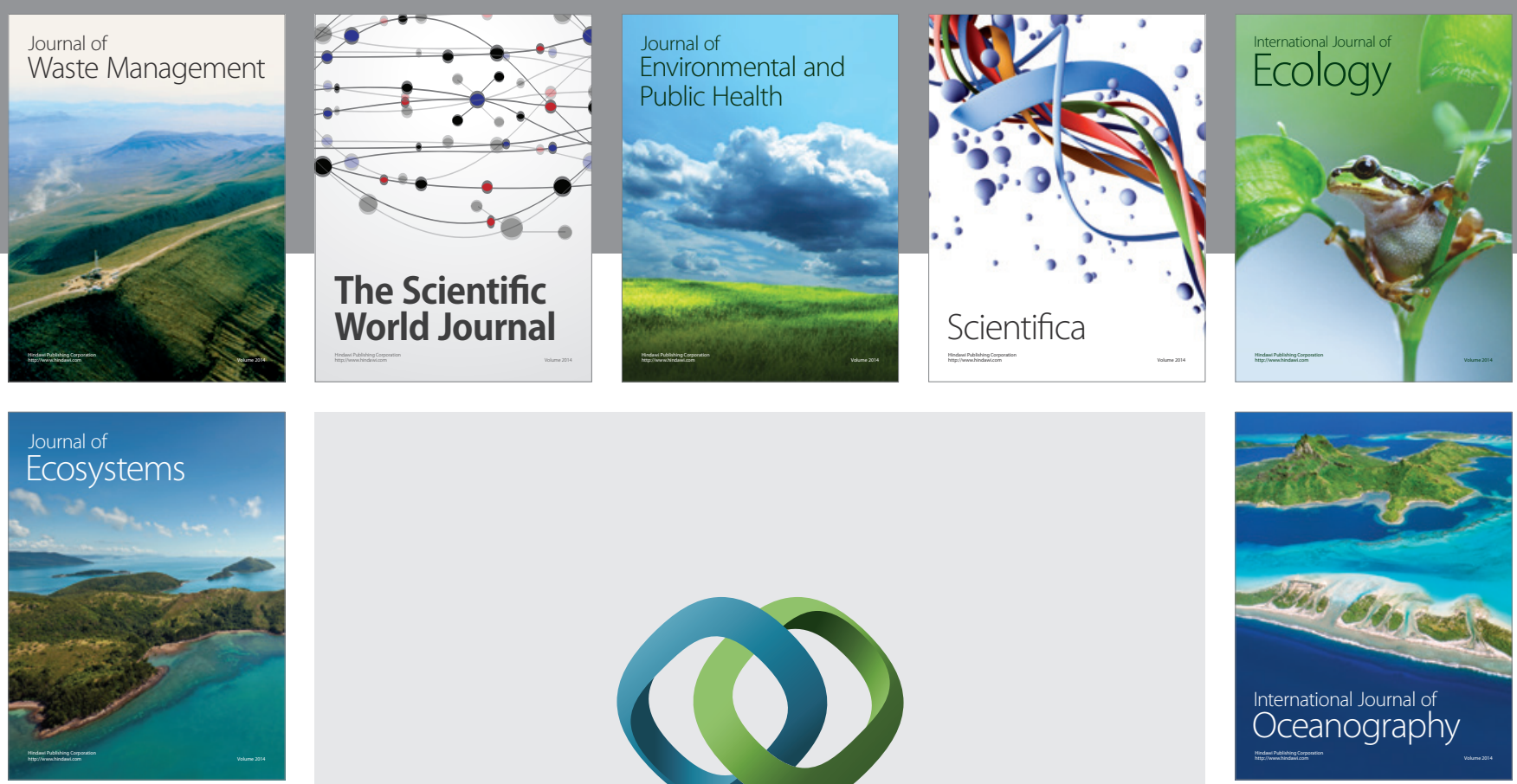

The Scientific World Journal
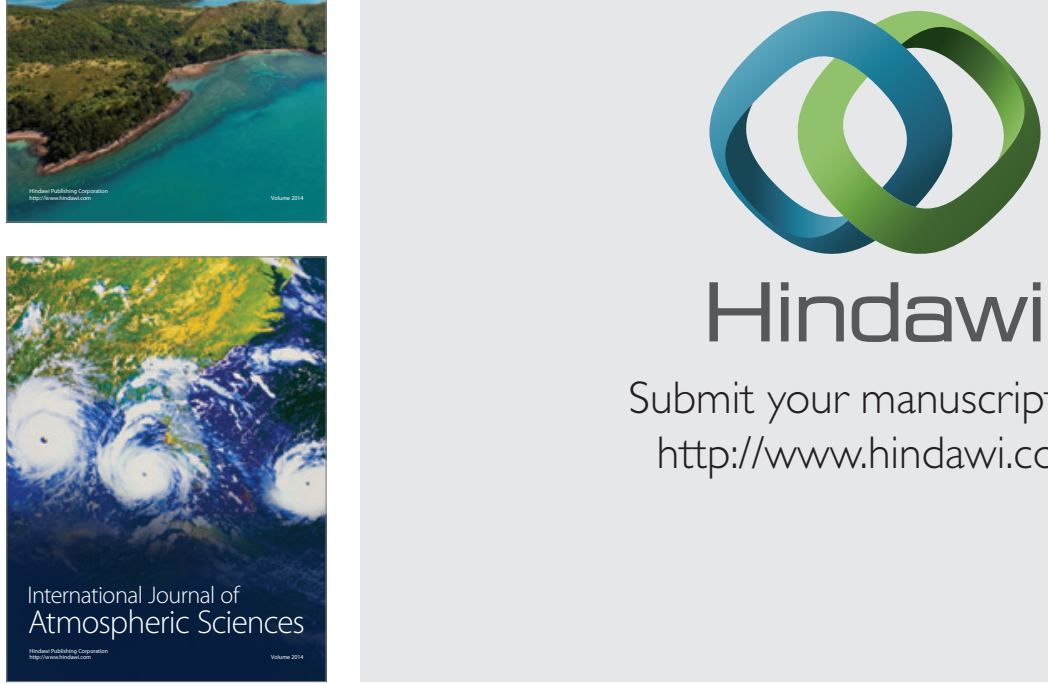

\section{Hindawi}

Submit your manuscripts at

http://www.hindawi.com
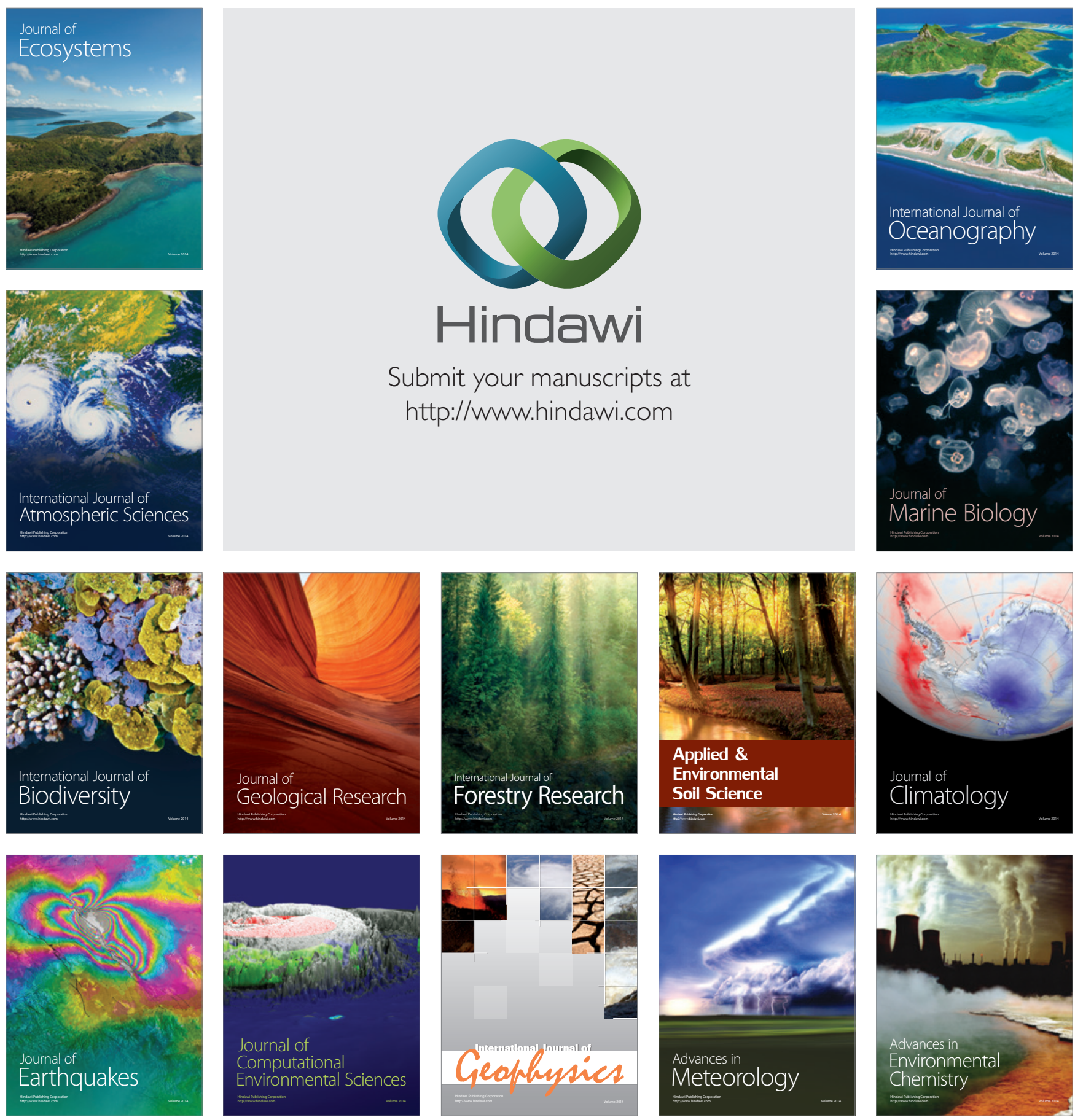